\title{
Türk Halı Sanatında Mitolojik Kaynaklı Bazı Motifler
}

\section{Some Mythology - Origined Motifs in the Art of Turkish Carpets}

\section{ÖZET}

Mitoloji, bir milletin en eski çağlardan itibaren atalarının hayallerini, tutkularını, yaşadıkları önemli olayları olağanüstü hikâyeler şeklinde anlatan destan, efsane ve masallardır. Bu Destan, efsane ve masallarda geçen önemli öğeler maddi kültür eserlerinde de görülmektedir.

Milletlerin tarih sahnesinde sürekli kalabilmesi ancak dilini ve kültürünü koruyabilmesi ile mümkün olmuştur. Bu nedenle de meydana getirdiği sanat eserlerini kendi kültürel damgasını vurmuş; geliştirmiş olduğu estetik kriterleri bu eserlerde ortaya koymuştur.

Maddi kültürümüzün önemli bir kısmını oluşturan halı ve kilimlerimizdir. Bu halı ve kilimlerimizin yüzeylerinin süslenmesinde yer alan motifler, milletimizin geçmiş çağlardaki inançlarını ve yaşam felsefesini en iyi şekilde yansıtmaktadır. Halı ve kilimlerimizin her biri ayrı bir sanat eseri değerinde olup, yüzeylerinde yer alan motifler içerdikleri anlam bakımından geçmişten günümüze önemli ipuçları sunmaktadır.

Bu çalışmada Türk halı ve kilimlerinde eski inançların ve yaşam felsefesinin

İzlerini taşıyan motiflerden bazı örnekler sunulacak ve bunlarla ilgili açıklamalar yapılacaktır.

Anahtar Kelimeler: Türk, Halı, Mitoloji, Motif, Masal, Destan.

\section{ABSTRACT}

Mythology is a nation's legends, myths, fables telling their anchestor's dreams, ambitions and important events in the form of extraordinary tales since the ancient times.

The important elements in these legends and fables have also been seen in tangible culture works.

For the nations, to be permenant in the history scene can only be possible by preserving their language and and their culture. That's why They have the impressions in their own art works, and also they show their criterias in their, art works.

Carpets take important place in our tangible culture. Motifs used in carpets have reflected our nations' belief and life philosophy of the past. Each carpet is an example of work of art.The motifs used in these carpets present important clues by means of their meanings.

In this study, examples of carpets reflecting old beliefs and life in Turkish carpet art will be presented and some explanations on motifs will be given.

Keywords: Turkish, Carpet, Mythology, Story, Motifs, Legend.

\section{Giriş}

Tarihte bilinen en eski Büyük Türk devleti M.Ö III. asrın ortalarından itibaren Asya'daki tüm kabileleri bir bayrak altında toplayarak ilk büyük Türk imparatorluğunu kuran Hunlardır. M.Ö 4. yüzyıl ile M.S.4 yüzyıl arasında varlıklarını sürdüren Hunlar hakkındaki 
ilk bilgiler Çin kaynaklarında yer almaktadır ((Ögel, 1984:43), Kafesoğlu 1982:57). Bu dönemde Orta Asya'dan geçen ipek yollarının kontrolünü elinde tutan Hunlar, Uzak Doğu ve Batı arasındaki ticareti kontrol etmişlerdi. Ticareti kontrol altında tutmaları sonucunda kültür etkileşimi daha fazla olmuş ve kendi sınırları içerisindeki gelişmeler lehlerine olmuştur (Ögel 1984:46).

Yapılan çeşitli arkeolojik araştırmalarda ortaya çıkarılan kurganlarda o dönemin yöneticilerine ait mezarlarda çok önemli eserler ortaya çıkarılmıştır. $\mathrm{Bu}$ kurganlardan biri Ordos yakınlarındaki NoinUla kurganlarıdır. Bu buluntular M.Ö birinci asra tarihlendirilmekte ve ele geçen eserler arasında elbiseler, şapkalar saç örgüleri kısa çizmeler, efsanevi aslan, yırtıcı hayvanların av sahneleri ve kulaklı kartal resimli tekstil parçaları bulunmuştur (Ögel 1984:58). Bir başka önemli kurgan topluluğunun bulunduğu yer ise Ural Altay Dağları eteklerindeki Pazırık Vadisinde bulunan Hun İmparatorluğu prenslerinin mezarlarıdır.Burada bulunan kurganlar araştırma sırasında numaralandırılmış ve yaklaşık kırk adet kurgan açılmış. Bu mezarlarda çok kıymetli eşyalar bulunmuştur Özellikle V. kurgandan çıkarılan eşyalar arasında, çok çeşitli kullanım eşyaları at arabası kap-kacak, altından yapılmış taç dokuma kumaşlar, kilimler, keçeler, kadın baş takısı, araba dingilleri ve parçaları, masa ayakları, keçi ve koyun başları, kemikten yapılmış davul kasnağı, at cesedi, kapaklı tabut, at koşum takımları ile birlikte sağlam kalabilmiş halı bulunmuştur (Tekçe 1993:20). Bu V numaralı kurgandan çıkarılan halı, bilinen en eski halıdır ve Türk düğümüyle dokunmuştur. Dokuma kültürümüzün oluşumunda, milletimizin yaşadığı tabii şartlar, yaşam tarzı ve inanışları etkili olmuştur. Konar-göçer bir yaşam tarzına sahip olan atalarımız soğuk iklimde kendilerini ve atlarını soğuktan korumak için halı dokuma tekniğini bulmuşlardır. Bu teknikte yapılan halılar, hükümdarların saraylarını, rahiplerin ve zenginlerin evlerini süsleyen en kıymetli dokumalar olmuştur. Bugün Rusya'nın Saint Petersburg şehrindeki Ermitag Müzesinde sergilenen halı, 189X200 cm ebatlarındadır (Yetkin 1974:12).

Maddi kültürümüzün önemli bir bölümünü halı ve kilimlerimiz oluşturur. Halı ve kilimlerimizin tarihi milletimizin tarihi kadar köklü bir geçmişe sahiptir.

Halı ve kilimlerimizin kompozisyonlarını oluşturan motifler ise eski inanç ve yaşam kültürümüzle yakından ilgilidir. Bu motiflerin tek tek incelenmesi çok kapsamlı bir araştırmayı gerektirdiğinden araştırmayı dört motifle sınırlı tutmak istedim.Bu motifler, geyik, kartal, hayat ağacı ve ejderhadır.
Geyik: Geyik figürlü resimler buzul çağına kadar indirilebilmektedir. Bu tür resimleri içeren buluntular Güney doğu Asya ve Çin'den İskandinav ülkelerine kadar geniş bir coğrafyada ortaya çıkarılmıştır. Geyik figürlerini şekillendirmede kullanılan ilk maddeler, hayvan kökenli doğal organik malzemelerdir. Daha çok hayvan kemikleri, boynuzları ve dişleri kullanılmıştır. Bu tür malzemelerinin tercih edilmesinin sebebinin totemik inançlardan dolayı olduğu ifade edilmekte (Mülayim 1999:38).

Proto Türk devrinde sı̆̆ın geyikleri Gök dinini, kozmik ya da totemle ilgili kavramlarla bağlantılı olarak ata ruhunu ve beylik kut'u ongununu temsil ettiği düşünülmekteydi. Hükümdarların mezarları takdis edilirken kurban edilen hayvanın başka bir âlemde tekrar canlandığına ve olağanüstü bir mana kazandığına inanılıyordu. Sığın geyikleri bazen ölümsüzlük otunun bulunduğu dağ veya hayali bir âlemdeki bitkilerle de tasvir edilmiş olduğu bilinmektedir. I.binde Orta Asya'dan gerçekleşen göç hareketleri neticesinde sı̆̆ın geyik figürlü dikili taşlar çok geniş bir coğrafyada görülürler ve boyları oldukça büyüktür. En eski geyik figürlü dikili taşlar, M.Ö. VII- VIII. yüzyıla ait dikilitaşlardır ve Yenisey bölgesinde bulunmuştur (Esin 2006:213).

Hun imparatorluğu dönemine ait Pazırık kurganlarından çıkan eşyalar arasında hayvan maskları da bulunmaktadır. Bu dönemde oluşturulan ve daha çok hayvan figürleri içeren örneklerden dolayı "Hayvan üslûbu" olarak adlandırılan sanat eserleri arasında geyik figürleri önemli yer tutar. Keçeler üzerine aplike edilerek işlenmiş hayvan mücadele sahnelerinde genellikle geyik- kartal mücadelesi veya pars-geyik mücadelesi yer alır Tekçe 1993:112). $\mathrm{Bu}$ mücadele sahnelerinde geyik motifinin daha sık rastlanmasının sebebi geyiğin kutsal bir av hayvanı olması ve hükümdarların mezarları takdis edilirken kurban edilen av hayvanı olması olmasıdır (Esin 2006:214). En eski Türk destanlarından olan Oğuz Kağan destanında Oğuz Kağan'ın ata binip, avlandığı ve av sırasında geyik avladığı anlatılmaktadır (Banarlı 1971:18). İslami Dönem Türk Edebiyatının en eski yazılı eserlerinden olan Dede Korkut Hikâyelerinden Bamsı Beyrek'te Oğuz'un üzerine bir sürü geyik geldiği ve Beyrek'in bunlardan birini kovalayarak gittiği yerde yeşil çayırın üzerine kırmızı bir otağın kurulu olduğunu ve bu otağın beşik kertmesi nişanlısı Banu Çiçek'e ait olduğunu öğrenince geyiği avlayarak Banu Çiçek'e hediye ettiği anlatılmaktadır (Ergin 2007:62-63).

Geyik, aynı zamanda Türklerde kutsal sayılan bir hayvandır. Bu nedenle Türk mitolojisinde önemli bir yere sahiptir. Türk efsanelerinde geçen geyik dişi geyiktir. Özellikle Sibirya tundralarında yaşayan 


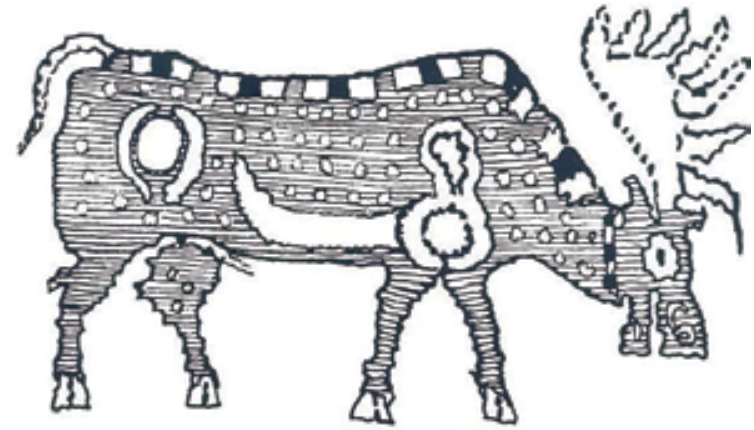

Çizim 1. Geyik Motifi Çizimi (F. Tekçe'den)

topluluklar arasında ren geyiği ile ilgili bazı türeyiş inanışları da yer almaktaydı. Bunlar Tanrı ile ilişkisi olan birer dişi ilahe durumundaydılar. Çin kaynaklarında yer alan bilgilere göre Göktürk devrine ait bir efsanede Göktürklerin atalarından bir bey sık sık bir mağaraya giderek orada dişi bir deniz tanrısı ile sevişirmiş. Bu ikisi arasındaki aşk devam ederken günün birinde bu bey, bir sürek avı düzenlemiş. Av sırasında askerleri idare eden komutanlarından birisi, önüne çıkan "ak geyiğgi” öldürmüş. Bundan sonra sevgilisini yerinde bulamayan Göktürk Beyi, o geyiği öldüren komutanı cezalandırmış (Ögel 1998:569). Ak'lık (beyaz) Altay Şamanizm'inde ilahelere mahsus bir renk olarak görülürdü. Aslında ak sözcüğ̈üün anlamı temizlik, paklıktır. Aynı zamanda dişi geyikler Göktürkler devrinde iyilik getiren kutsal bir hayvan olarak da tasavvur edilmişlerdir (Ögel 1998:573).

Göktürk abidelerinde yer alan geyik ve geyik avı ile ilgili bilgiler de geyiğin bir ongun olduğunu göstermekte. Çin kaynaklarında yer alan Göktürklerle ilgili efsanelerden birinde geyik mukaddes bir hayvan olarak zikredilmekte (Esin 2003:206).Yine Göktürk Kağan soyunun "sığın geyik" ongunlarıyla ilgisinin olduğu Toharistan Yabgularına ait sikkelerde de ortaya çıkarılmış. Göktürk Hakanlarından“Tong Yabgu'nun Talas yakınlarındaki ormanlarda evcilleştirilmiş "sığın geyikleri" olduğu; bunların boyunlarında çıngıraklarının bulunduğu bilgisi Çin kaynaklarında yer almaktadır (Esin 2003:207).

Cengiz Han'ın ataları ile ilgili bir efsanede ise, Cengiz Han'ın atası Gök kurt ile karısı kızılımsı geyiktir. Bunların gökte doğduklarına inanılırdı (Ögel 1998:570).

Kırgızlarda geyik, totem gibi kabul edilirdi. Bazı Kırgız şamanlar kendi koruyucu ruhlarının geyik ve ak maral olduğuna inanırlar. Kırgızların Kozı Körpeş Destanında geyik motifi yer alır (Atnur 2005:213). Türk boylarında geyik, balan, bugı, bulan, bugu, s1gun, buğa, sığın, mıygak adlarıyla anılır. Kökü Mezolitik devre kadar inen geyik, şamanlara ait giysilerin, Şamanist törenlerin, el sanatlarındaki muhtelif simgelerin ve Türk halk hikâye ve masallarında, inanışla- rında vazgeçilemeyen kutsal hayvanlardandır (Atnur 2005:215)

Bozkır göçebelerinin Anadolu'ya kadar gelen öykülerinde geyik ölmekle yok olmaz göğe gider. Sibirya ve Orta Asya budunları işte bu nedenle ruhları öteki dünyaya taşıdıklarına inanmışlardır (Tekçe 1993:116).

Türklerin İslamiyet'i kabulünden sonra ise geyik motifi, İslam'la ilişkilendirilmiş. Hem yazılı edebiyatımızda hem de halk kültürümüzde yaşatılmaya devam edilmiş. Anadolu'nun Türkleşmesinde ve İslamlaşmasında önemli yeri olan Hacı Bektaşi Veli, Abdal Musa, Geyikli Baba gibi dervişlerin hikâyelerinde, gösterdikleri kerametlerinde "geyik motifi" yer alır. Özellikle Anadolu'da XII.-XVI. asırdaki Tarikat ve Tekkelerde geliştirilen sanatta geyik figürü önemli yer alır. Tokat Niksar'daki Çöreği Büyük Tekkesinin portali üzerinde bir geyik kabartması vardır. Yine Tokat'ta bulunan Şeyh Meknun Türbesinin iç duvarlarına çizilmiş ve bir derviş tarafından çekilen iki geyik tasviri yer alır. Anadolu erenlerinden olan ve Bektaşi tarikatının kurucusu olan Hacı Bektaş-1 Veli koltuğunu altında bir geyikle tasvir edilmiştir (Karamamağaralı 1976:257).

Yazılı edebiyatımızda ise, daha çok mesnevi tarzında yazılan hikâyelerin içerisinde geyikle ilgili olanları vardır. Bunlardan biri, XII.-XIV yüzyılda yazılmış anonim bir tefsirde yer alan "Hamza ve geyik" hikayesidir (Aytaş 1999:163).

Bu gün bile Anadolu'nun pek çok yerinde anlatılan masal ve efsanelerde geyik motifi önemli yer tutar. Muğla yöresinde anlatılan "Anacık Babacık Tıntın Kabacık" adlı masalda geyik izinden su içen erkek çocuk, geyiğe dönüşür ve kız kardeşini tehlikelerden korur. Bu masalın anlatıldığı yöredeki bir dağın ismi de "Sı ̆̆ın Dağı"dır.

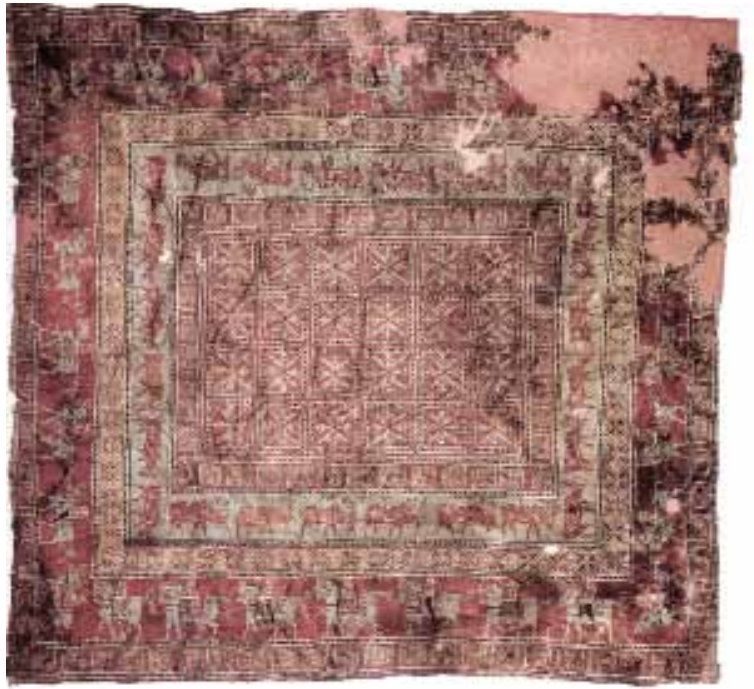

Foto 1. Pazırık Halısı (Fuat Tekçe'den) 


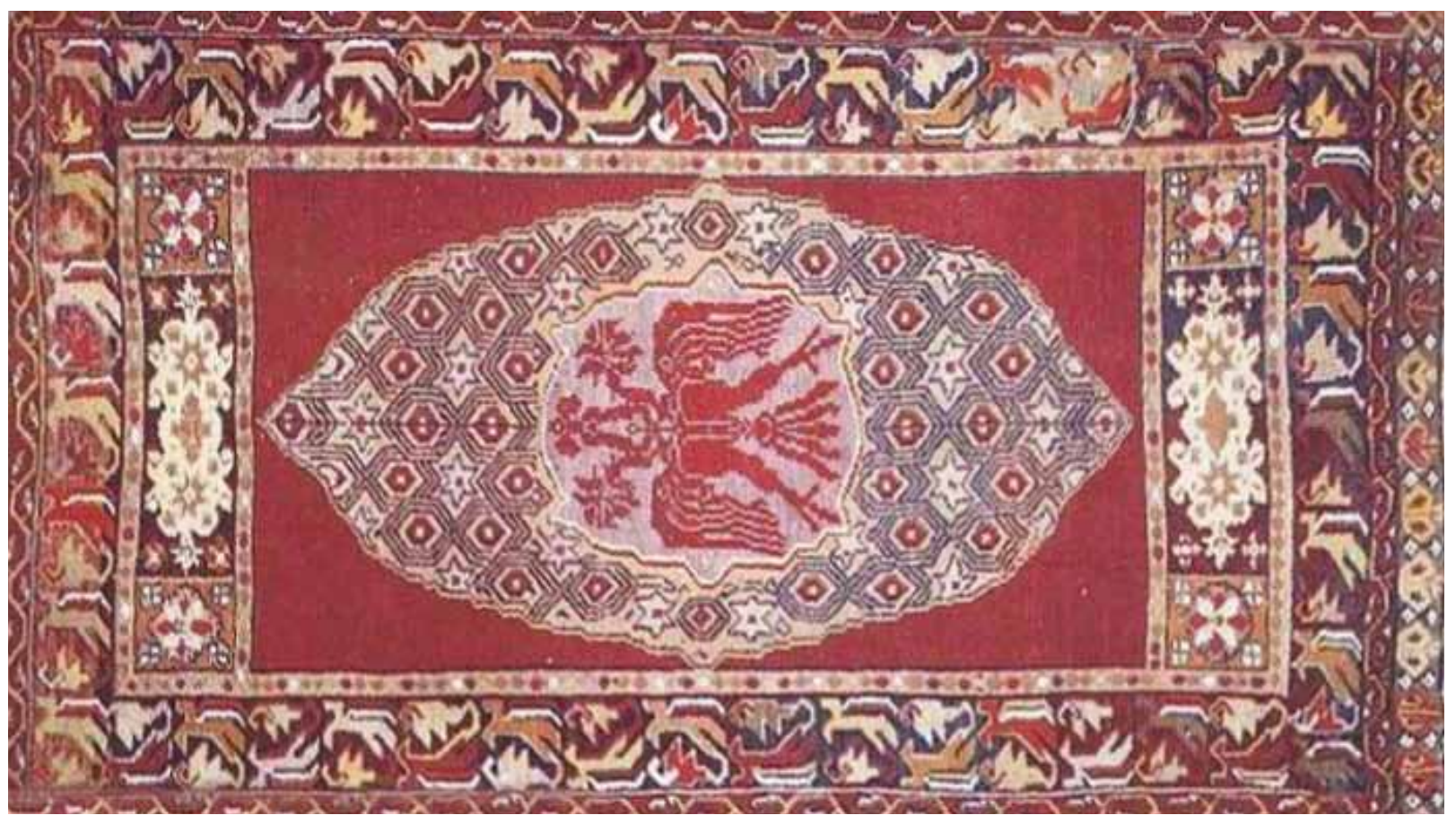

Foto 2. Çift başlı Kartallı Halı (N.Görgünay Kırzıoğlu'ndan)

Geyik motifinin kullanıldığı en eski örnekler Pazırık Kurganlarından çıkarılan tekstil ürünleri üzerinde yer alır. Pazırık Halısında ise içteki kalın suyunda sıralanmış olarak resmedilen geyikler realist bir üslûpla resmedilmişlerdir (Foto1-2). Geyikler burada çatallı boynuzlu ve benekli olarak işlenmişlerdir. Aynı kurganlarından çıkarılan keçe örtüler üzerinde yer alan geyikler de yine çatallı boynuzlu ve beneklidir. Keçeler üzerine aplike tekniğinde işlenmiş olan bu geyik motifleri yırtıcı hayvanlar tarafından saldırıya uğramış şekilde resmedilmişlerdir Hunlar döneminden kalma olan bu buluntuları Rudenko MÖ. V yüzyıla, Ghrisman ve Bussagli M.Ö 4-3. yüzyıla tarihlemişler. Nihayet bir çok araştırıcı ise M.Ö III yüzyıl ile İsa'nın doğumu arasına tarihlemişlerdir (Aslanapa, 1987:10).

Türklerin İslamiyet'i kabulünden sonraki dönemlerde süsleme tarzları değişmiş. Canlı resimleri daha çok stilize edilerek resmedilmeye başlanmıştır. Fustat'ta bulunan ve 14- 15. yüzyıllara tarihlendirilen halı parçalarının orta zemin düzenlemesinde sırt sırta yerleştirilmiş dört ayaklı boynuzlu hayvan figürleri geyiğe benzemektedir.

El Sanatlarımız içerisinde önemli yer tutan çok amaçlı olarak kullanılan keselerde. (Aytaç: Sanat ve İnsan sayı 2) ve işlemelerde geyik motifleri yer alır (Barışta 2001: 83).

Türk kültüründe geyik, uzun ömürlülüğü, ölümsüzlük otunu yemesinden dolayı ölümsüzlüğü sembolize etmektedir. Dünya folklorunda ise çabukluğu, hızlılığı, uzun ömürlülüğü, sevimliliği, sonbaharı, ayrıca boynuzlarıyla da güneşin ışıklarını temsil eder. Çin kültüründe ise, zenginlik ifadesidir (Atnur 2005:217).

Kartal: Oğuz boylarının yirmi dört olduğu ve her birinin bir kuş ongunu bulunduğu bilgisi yer almakta ve her boy isminin manası ile birlikte ongun kuşlarının adları yer almaktadır (Uzun 1996:85).

Anadolu Selçukluları dönemine tarihlenen ve bu gün Sieburg'da Apollinadi- Screin 'de bulunan Sırmalı Diba kumaşın üzerinde çift başlı kartal figürü yer alır. (Görgünay 2001:73)

Anadolu Türk halılarında kartal motifi 14. ve 15. yüzyıldan itibaren görülmeye başlar(Aslanapa 1987:37). Kaynaklara hayvan figürlü halılar olarak giren bu halı grubunda kartallar değişik şekillerde resmedilmişlerdir. Kartal figürünün işlendiği en güzel halı örnekleri, İtalyan ressamların tablolarında yer alır. Ressamların yaptığı tablolarda yer alan bu halılarda kartallar, tek ve karşılıklı duran kartal şeklindedir. Ressam Nicolo di Buonacorsa'nın (Ölümü 1370) yaptığı ve Londra National Galery'de sergilenen "Meryem'in Evlenmesi" adlı tablosunda sekizgenlerin içine başları arkaya dönük olarak kartal figürleri yerleştirilmiştir (Aslanapa 1987:50).

Erich Feigl koleksiyonunda bulunan Konya halısında, orta zemininde çift başlı kartal figürü yer almaktadır (Foto 3). Bu halıya benzer bir başka halı, ise halı tüccarı Hakan Tazecan'ın koleksiyonunda yer almaktadır (Görgünay 2001:294) (Foto 4). Bu halılarla benzerlik gösteren üçüncü halı ise Niğde müzesinde bulunan kartal figürlü halıdır (Çelik 2002:47). 


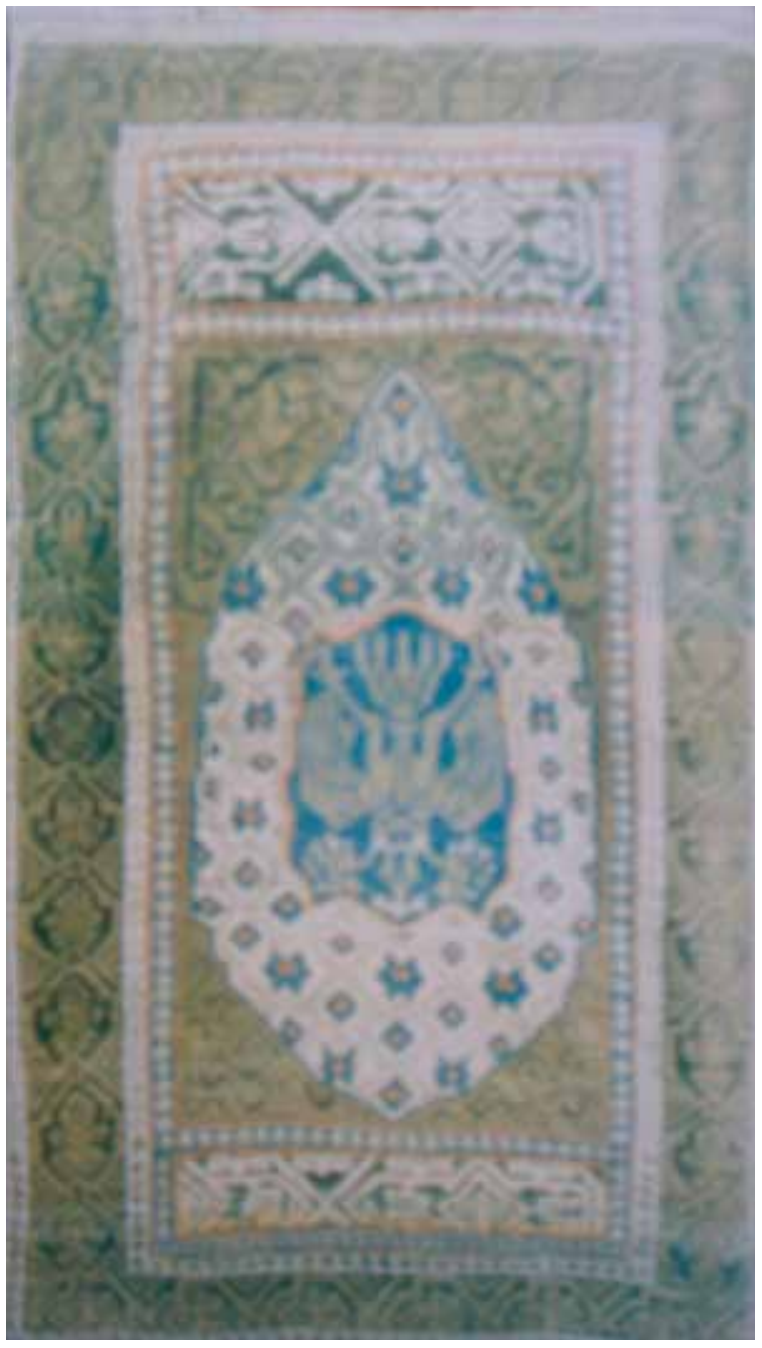

Foto 3. Çift başlı Kartallı Halı (N.Görgünay Kırzıŏlu'ndan)

Türk kültürünün en eski çağlarından itibaren kartal motifinin varlığını izleyebiliyoruz. Gerek destanlarda gerek masallarda gerekse çeşitli mimari eserlerde, heykellerde el sanatlarının çeşitli alanlarında kartal motifinin tek ve çift başlı olarak sıkça işlendiğini görüyoruz.

Altaylarda Telüt Türkleri efsanelerinde, merküt soyundan gelen bir boy vardı. Bunlara göre merküt, efsanevi ve kutsal bir "Gök kuşu" idi. Bu kuş o kadar büyüktü ki sol kanadını ayı, sağ kanadı güneşi kaplıyordu. Kuşların hükümdarı sayılan kartal dünya ağacının tepesinde tünemiş olarak tasavvur ediliyordu (Ögel 1998:599). Aynı zamanda Gök tanrının da sembolü idi. Bilhassa Şamanist Türk mitolojisinde bu hususa işaret eden çeşitli unsurlar bulunmaktadır.

Hunlar dönemine ait Pazırık Kurganlarından çıkarılan keçeden yapılmış eyer örtüleri üzerinde kartalın çift tırnaklı hayvanları öldürüşünü gösteren tasvirler yer alır (Tekçe 1993:11)

M.S 7.yüzyılda yapılan Göktürk anıtlarından Kültigin heykelinin başında kartal kabartması bulunan bir başlık görülmektedir. Kanatlarını iki yana açmış cepheden gösterilmiş olan kartalın hem bir arma hem hukuki bir sembol olduğu ifade edilmektedir (Karamağaralı 1970:78). Uygurlar döneminde Kızıl ve Hoço Budist mabetlerinde yer alan fresklerde çift başlı yırtıcı kuş tasvirleri yer alır (Çoruhlu 1999:245).

Kartal figürü, M.Ö yüzyıllarda yakın şarkta, Sümer, Elam, Babilonya kültür eserlerinde de önemli yer tutar. Roma ve Bizans'ta da kartal figürünün kullanıldığı bilinmektedir.

Anadolu Türk Sanatında XII. yüzyıldan itibaren görülmeye başlayan kartal figürü, Konya kalesinin kabartmalarında, Sivas Divriği Ulu Camisinin batı kapısı üzerinde iyi ve sağlam kalmış örneklerdir. Selçuklu Sultanlarından I. Alaaddin Keykubat'ın çift başlı kartalı, arma olarak kullandığını döneminin sikkelerinden anlayabiliyoruz (Parlar 2000:150) Sikkelerde yer alan aynı figürler, Beyşehir Gölü kenarındaki yazlık sarayının kazılarında ortaya çıkarılan çini levhalar üzerinde de yer alır. Sarayın çini süslemelerinde pek çok realist üslupta resmedilmiş gerçek hayvan figürleri ile mitolojik kaynaklı hayvan figürleri yer almaktadır. Bunlardan birisi de çift başlı kartal armasıdır. Bu armada yer alan kartal figürünün göğsünün üzerinde "es sultan" ibaresi yazılıdır (Önder 1985:17), (Arık 2000:78 ), (Foto 5).

Kartal motifi günümüzde Anadolu'nun pek çok yerinde anlatılan masallarda yer alır. Bazı yörelerde ise kartal motifi, "karakuş" olarak geçer. Örneğin, Muğla yöresindeki bir masalda yer altı dünyasında çam ağacının başına yuva yapmış ve yavrulamış şekilde geçer. Yapılan bir iyiliğe iyilikle karşılık verdiğinden, iyiliğin simgesi durumundadır.

Kartal motifi, halılarımızda güç, kuvvet ve kudret ve hâkimiyetin sembolü olmuştur. Halı ve kilimlerimizde realist olarak işlenmiş örneklerin yanı sıra stilize edilmiş ve geometrikleştirilmiş örnekleri de mevcuttur.

Hayat Ağacı: Hayat ağacıyla ilgili inanışlar ve semboller tüm dünya kültürlerinde yer alır (Ergun 2008:147).

Türk kültüründe ise, hayat ağacı bütün inanışların kaynağı durumunda olup üç alemi birbirine bağlayan mitolojik bir motiftir. Doğum, hayat, ölüm ve ölüm sonrasında devam eden yoldur. Ağaçla ilgili en güzel efsaneler Orta Asya'da derlenmiştir.

Kırgızların Manas destanında, aksakallı ihtiyarın çocuğa seslendiği ve Tanrıdan iyi haber getirdiği yer bir kayın ağacının tepesidir (Ögel 1998: 96).

Yakutların Er-Sogotoh efsanesinde ise, hayat ağacı ile ilgili çeşitli unsurlar bulunmaktadır. Bu unsurlardan biri dünyanın sarı göbeğinden çıkan bir ağaç göğün yedinci katına uzanırdı. Cennet ise, göğün yedinci katının üzerinde ve ortasında bulunuyordu (Ögel 1998:100) . 


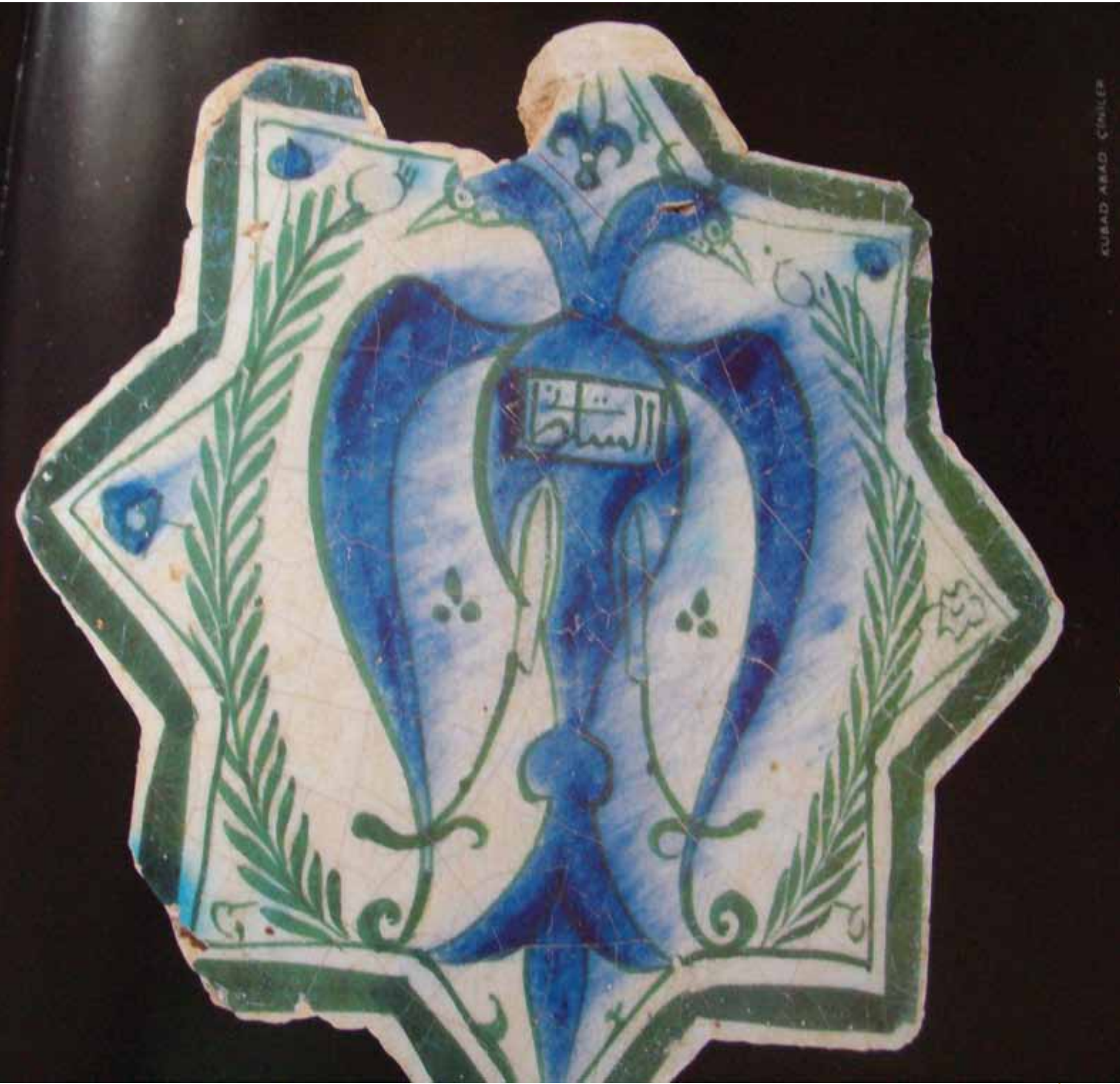

Foto 4. Çift Başlı Kartal Motifili Çini (R.Arık'tan)

Türk tarihinin her döneminde ağaç, saygı görmüş ve hayranlık uyandırmıştı. Özellikle yaşlı geniş gövdeli yüksek tepeli ağaçların yanlarından geçen insanlar, bu ağaçların önlerinde diz çökerek onlara saygılarını sunarlardı. Yakutlar ulu ağaçlara bir armağan vermeden önünden geçmezlerdi. Bu gün bile Anadolu'nun pek çok yerinde "kutsal ağaç kültü" hâlâ yaşamaktadır.
Türklerin ongun hayvanlardan sonra en çok kullandıkları motiflerden biri hayat ağacıdır. Piktogram olarak en çok değer verilen bitkisel karakterli motiftir. (Gülensoy 1989:50)

Türk destanlarının pek çok yerinde yer alan 'hayat ağacı' Altay mitolojisine göre gökyüzüne yükselen çok büyük bir çam ağacıydı. Gökleri delip çıkan bu ağacın tepesinde Tanrı Bay Tigen otururdu. Şaman 


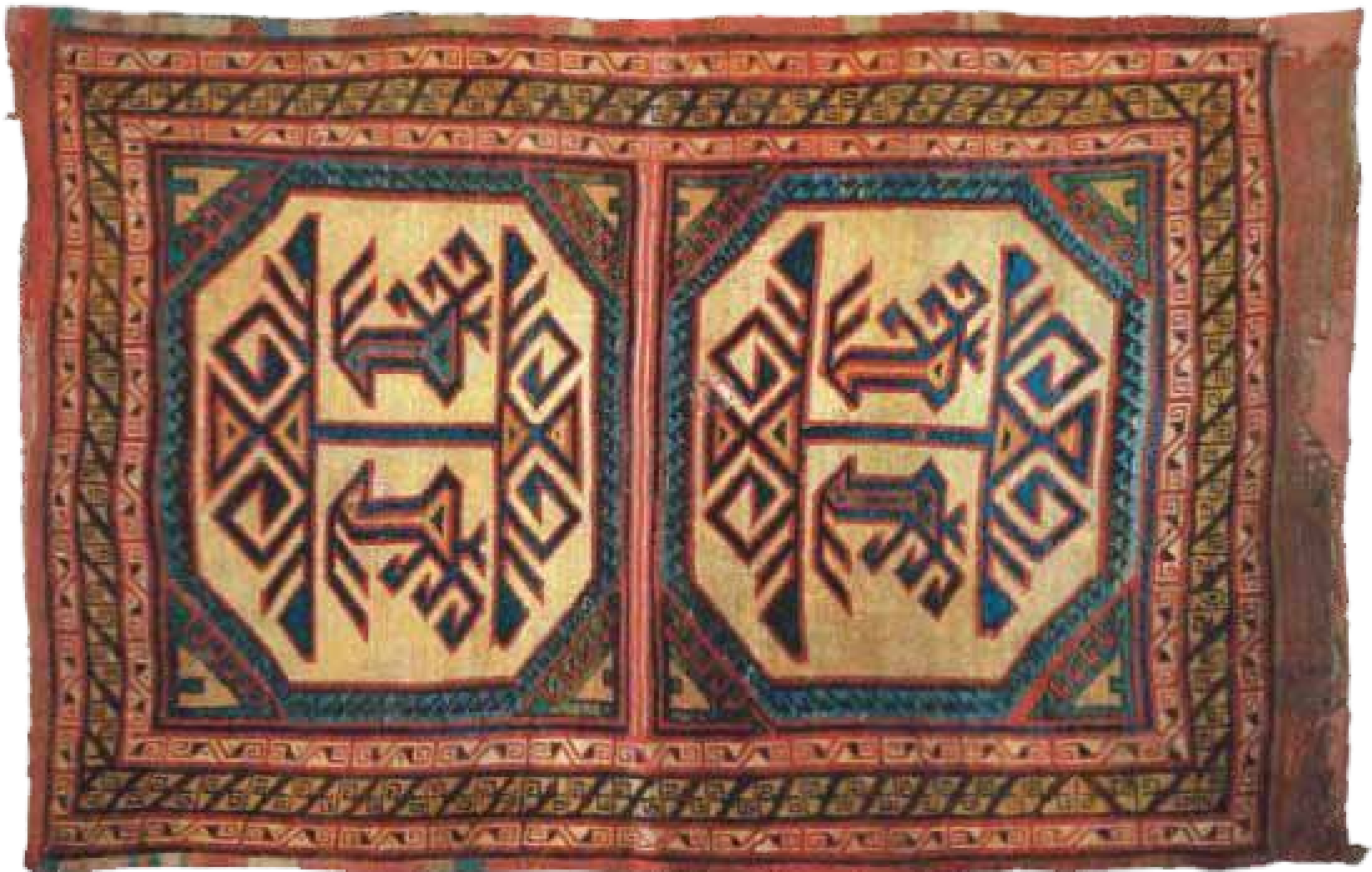

Foto 5. Hayat Ağaçlı Halı(Marby Halısı) Kültür Bakanlığı, Halı Katolog 4, Model Kodu:0435

davullarında bu ağacın kökleri dünyada değil daha çok göğün başladığı yerden itibaren gösteriliyordu. Altay yaratılış destanlarında anlatıldığı üzere bu ağacın dokuz dalı bulunuyor. Bu ağaca aynı zamanda "gök ağacı" da deniyordu. Bu ağaçlar genellikle gökteki bir dağ veya tepe üzerinde yer alıyor, bir yanında ay, diğer yanında güneş yer alıyordu (Gülensoy 1989:50).

Sibirya'da yaşayan Abakan Tatarlarında bu görüş biraz daha değişmiş şekildedir. Onlara göre dünyanın ortasında göklere kadar yükselen demir bir dağ vardı. Bu dağın üzerinde yedi dallı bir kayın ağacı bulunduğuna, bu ağacın dokuz dalının altından dokuz insanın yaratıldığına, dokuz insandan da dokuz oymağın türediğine inanılmaktadır.

Uygurların türeyiş destanında da atalarını türediği ağacın köklerinden kaynayan otuz su kaynağının bulunduğu yerden otuz oymak meydana gelişi yer alır (Ergun 2004:147).

Hayat ağacı inancı tüm dünya kültürlerinde en yaygın inançlardan biridir. Aynı zamanda, ağaç kültüyle ilgili tüm inançların kökeninde "hayat ağacı" kültü yatmaktadır. Gözle görülen çeşitli vasıfları ile gerçekçi bir saygı gören ağaç, aynı zamanda mitolojik bir sembol olarak birçok mucizeyi gerçekleştirir. O, öncelikle hayat bahşeder ve üç âlemi birbirine bağlar. Kabile toplumunun bütünlüğünü temsil eder. Bir başka deyişle bu olağanüstü ağaç hem can- lıların (özellikle insanların) üç âlemdeki işlerini düzenler. Hem dünyanın düzenini sağlar, hem de içinde bulunduğu topluma ortak bir bağ, dayanışma ve yakınlık sağlar. Hayat ağacının temel vasfı ise, ebedi canlilıktır (Ergun 2004:145).

Hayat ağacı aynı zamanda ölümün de sembolüdür. Türk inancında beden ölür ama, ruh ölmez. Hayat ağacı ruha, yukarı ya da aşağı gideceği yolu gösterir.

Osmanlı Türklerinin inancına göre ise, hayat ağacının dünyadaki insan sayısı kadar yaprağı vardır. Her yaprağın üzerinde bir insanın kaderi yazılı olduğuna ve o yaprak düştüğünde o insanın öleceğine inanılırdı (Ergun 2004:147). Yine, Osmanlı dönemi Türk kültüründe "Hayat Ağacı" aynı zamanda güç ve iktidar sembolüdür. "Devletlû kaba ağaç" deyimiyle sembolize edilmiştir. Osman Gazi'nin rüyasında gördüğg̈ kendi göbeğinden çıkan bir ağacın tüm dünyayı sarması, Osman Bey'in devletinin, dünya hâkimiyeti kuracağına yorumlanmıştır.

Zerdüşt inancında ise ağaç, sağlık ve şifa sembolüdür (Beksaç 1988:66).

Bu gün Anadolu'nu pek çok yerinde ağaçla ilgili inanışlar devam etmektedir. Özellikle subaşlarındaki ve yüksek dağ tepelerindeki 'ulu ağaç'lar halk tarafından kutsal sayılır

Türk sanatının her devrinde ve her kolunda karşımıza çıkan hayat ağacı en çok işlenen motiftir. Mi- 


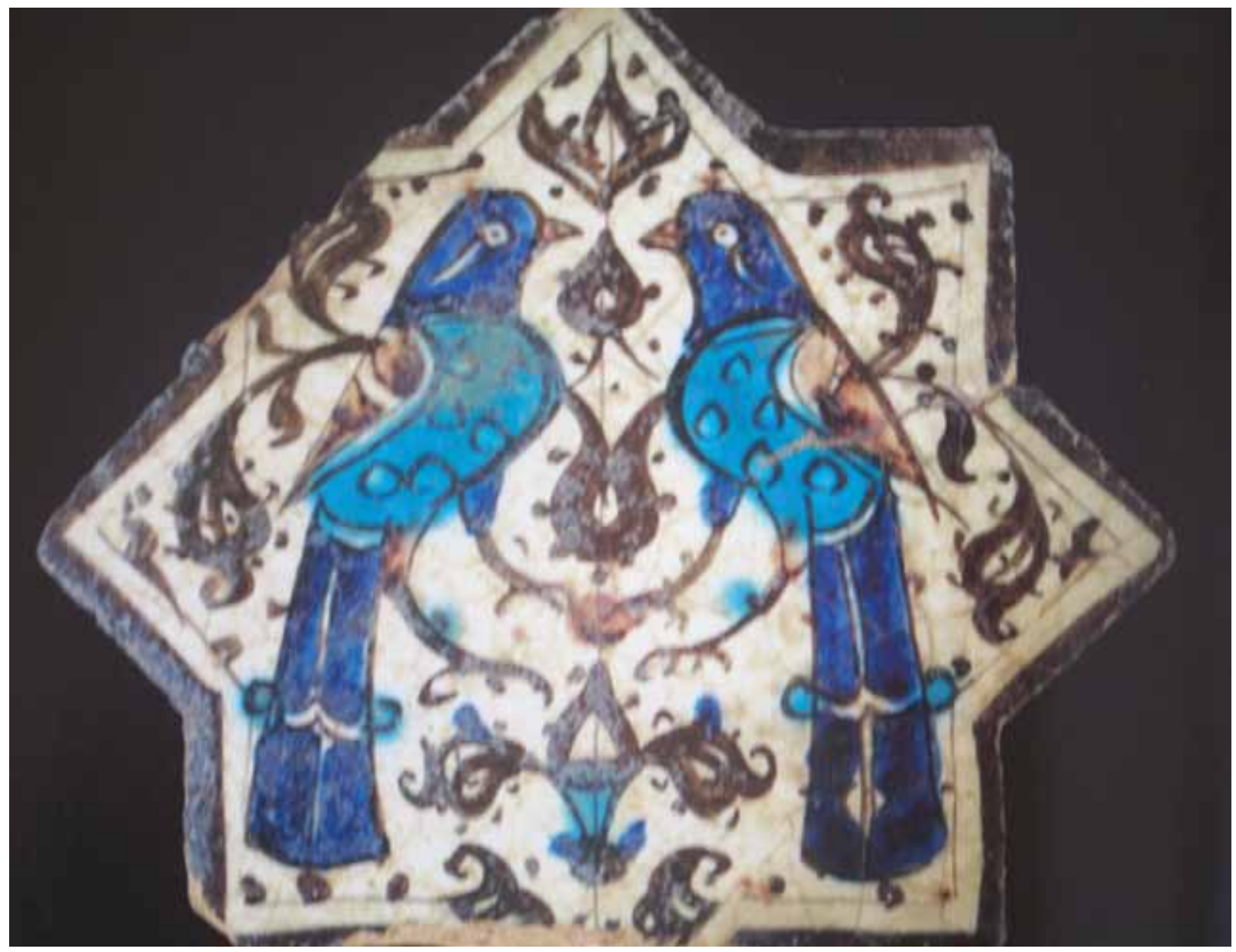

Foto 6. Hayat Ağacı Motifli Kuşlu Çini (R.Arık'tan)

mari eserlerin taş kabartmalarında (Erzurum Çifte Minareli Medrese portali) Anadolu Selçuklu Hükümdarlarından I.Alaaddin Keykubat'ın, Kubad Abad Sarayı çini levhalarında stilize şekilde Hayat ağacı motifleri yer alır. Bu stilize edilmiş bitki motifinin yanında çeşitli şekillerde resmedilmiş kuş figürleri yer alır (Arık 2000:93). Meyveli ve yapraklı hayat ağacı motiflerini, Gönül Öney'in ebedi cennet simgesi olarak yorumladığı bilgisi yer almaktadır (Arık 2000:174). Osmanlı Dönemi çini örneklerinde ise bahar dalı şeklinde yer alır.Buna en güzel örnek, Topkapı Sarayı sünnet odası çinileridir. (Aslanapa 1984:327). mezar taşlarında ve minyatürlerde de hayat ağacı motifi yer alır Varka ve Gülşah yazmasındaki 28. resim buna örnek verilebilir) (İnal 1995:res. 28), ahşaptan yapılmış eserlerde geleneksel Milas ev kapılarında ve Milas halılarında çeşitli şekillerde işlenmişlerdir.

Hayat ağacı Motifinin işlendiği en eski tarihli halı örnekleri 14. ve 15. yüzyıla tarihlendirilen hayvan figürlü halılarda görülmektedir. Bu güne ulaşmış ve sağlam kalabilmiş en güzel örnek 'Marby Halısı' olarak adlandırılan halıdır. Bu halının zemini iki dikdörtgen panel şeklinde olup ortasında sekizgen ve bu se- kizgenin içinde bir ağacın iki yanında yüz yüze durmuş kuş figürleri yer alır (Foto 6). Bu tip kompozisyona sahip çini levhalar Kubad Abad Sarayı çinilerinde bol miktarda vardır. Bazen kuşlar sırt sırta durmuş, bazen de başlarını geriye dönmüş şekilde bazen de yüz yüze resmedilmişlerdir (Foto 7). (Arık 2000:799). Aynı tür kompozisyonu içeren halı parçaları Fustat'da bulunmuştur. Bu halılar da XV. yüzyıla tarihlendirilmektedir.Yine bir başka sağlam kalabilmiş halı örneği Türk İslam eserleri müzesinde sergilenen Sivrihisar Camiinde bulunup müzeye intikal ettirilen halıdır.

Hayat ağacı motifi tüm yöresel halı ve kilimlerimizin orta zemin süslemesinde yer alır. Milas halılarında ise bu motif, orta zeminde bazen tütün yaprağı (Foto 8.), bazen buğday başağı, (Foto 9. mod. kod. 0153- )Tek taraflı boğumlu mihraplı Milas halılarında mihrap tepesinden yükselir .Hayat Ağacı motifi, tüm yöresel halı ve kilimlerimizde en sık kullanılan ortak motiflerden biridir.

Halı ve kilimlerimizde yer alan bu motif, ölümsüzlüğü, ebedi cenneti, soyun ve hayatın devamlılığını simgelemektedir. Halk arasında soy kavramı, soy ağacı veya soy kütüğü şeklinde ifade edilmektedir. 


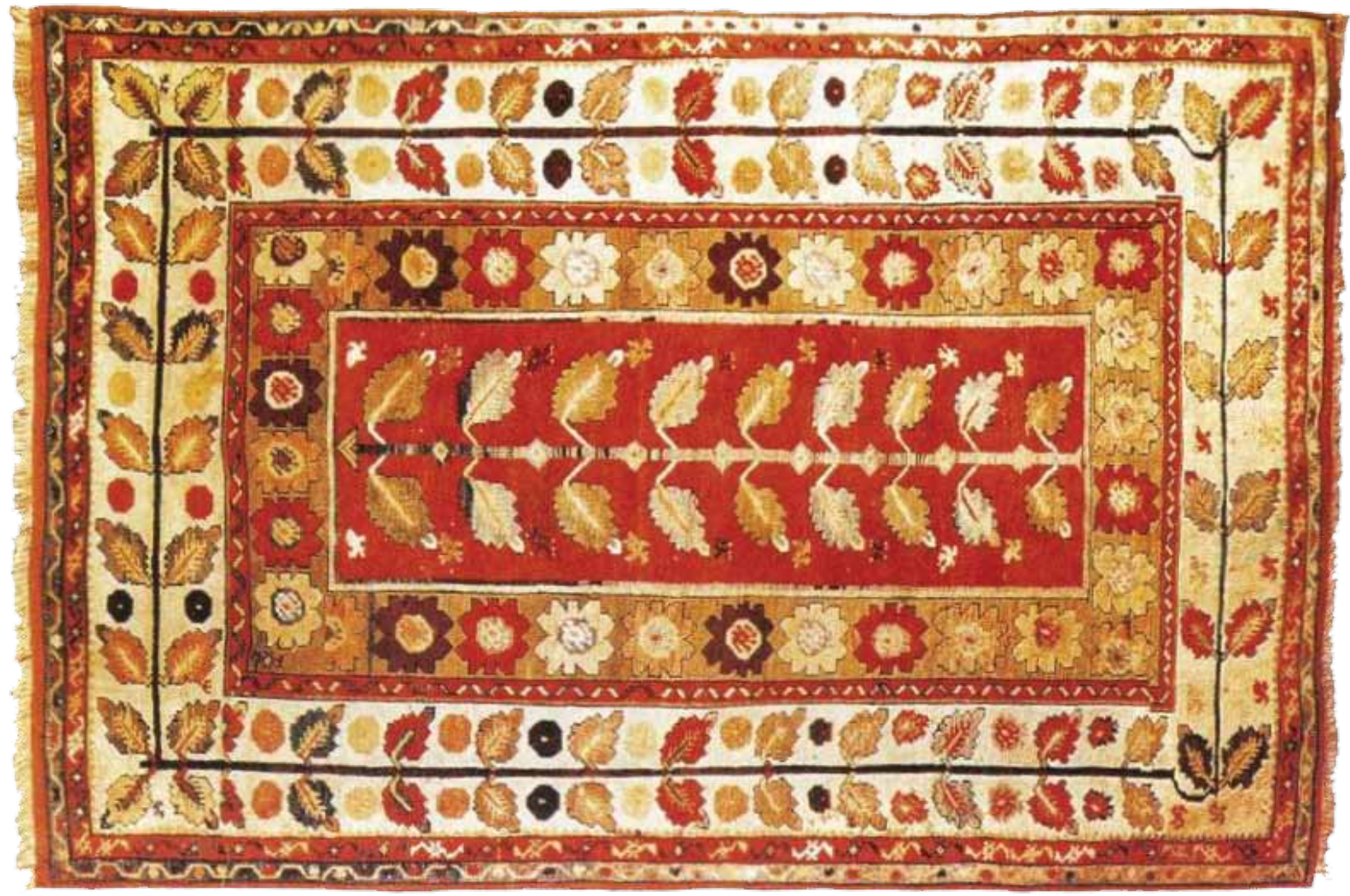

Foto 7. Tütünlü Milas Halısı, Hayat Ağacı Motifli, Model Kodu:0123

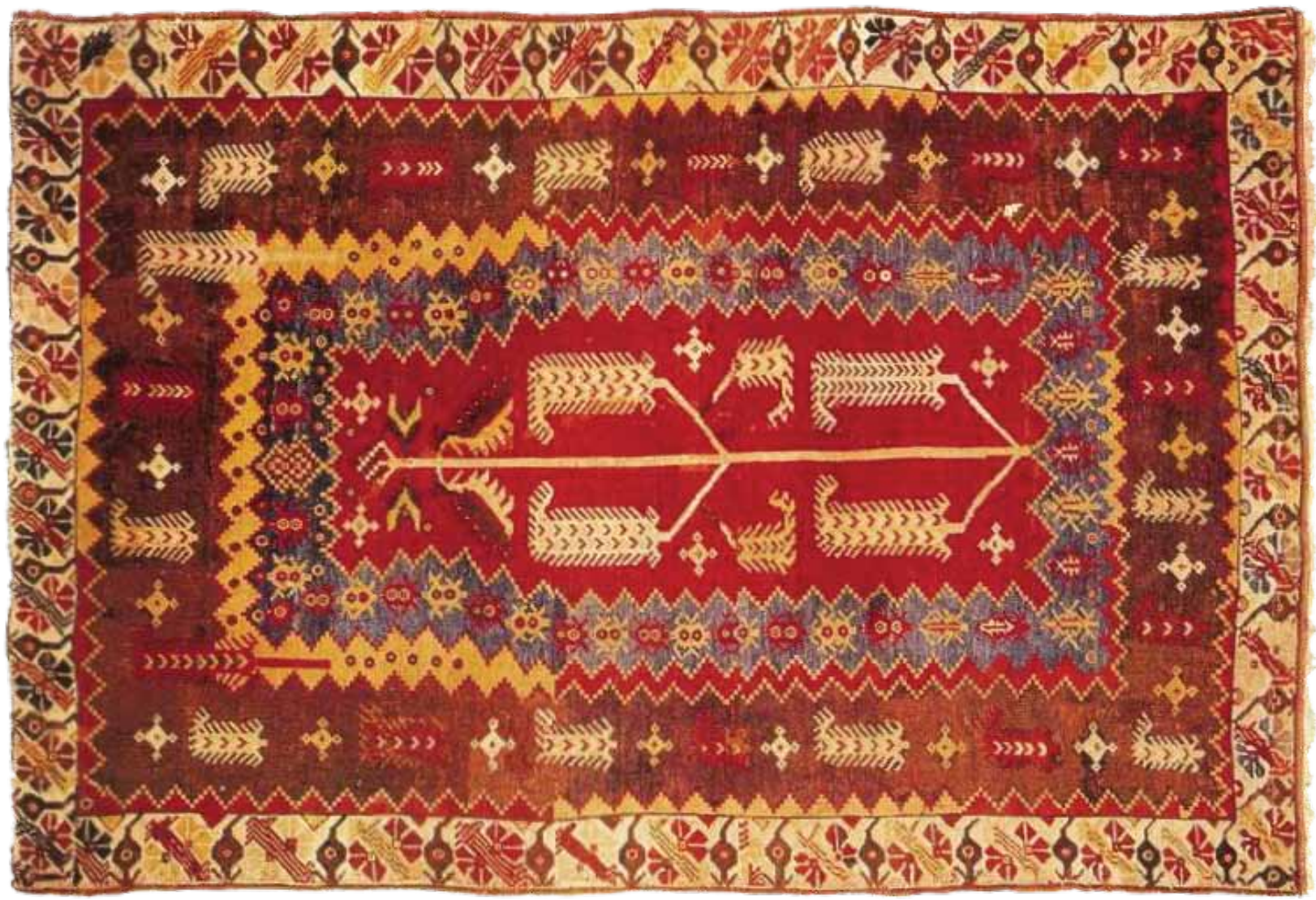




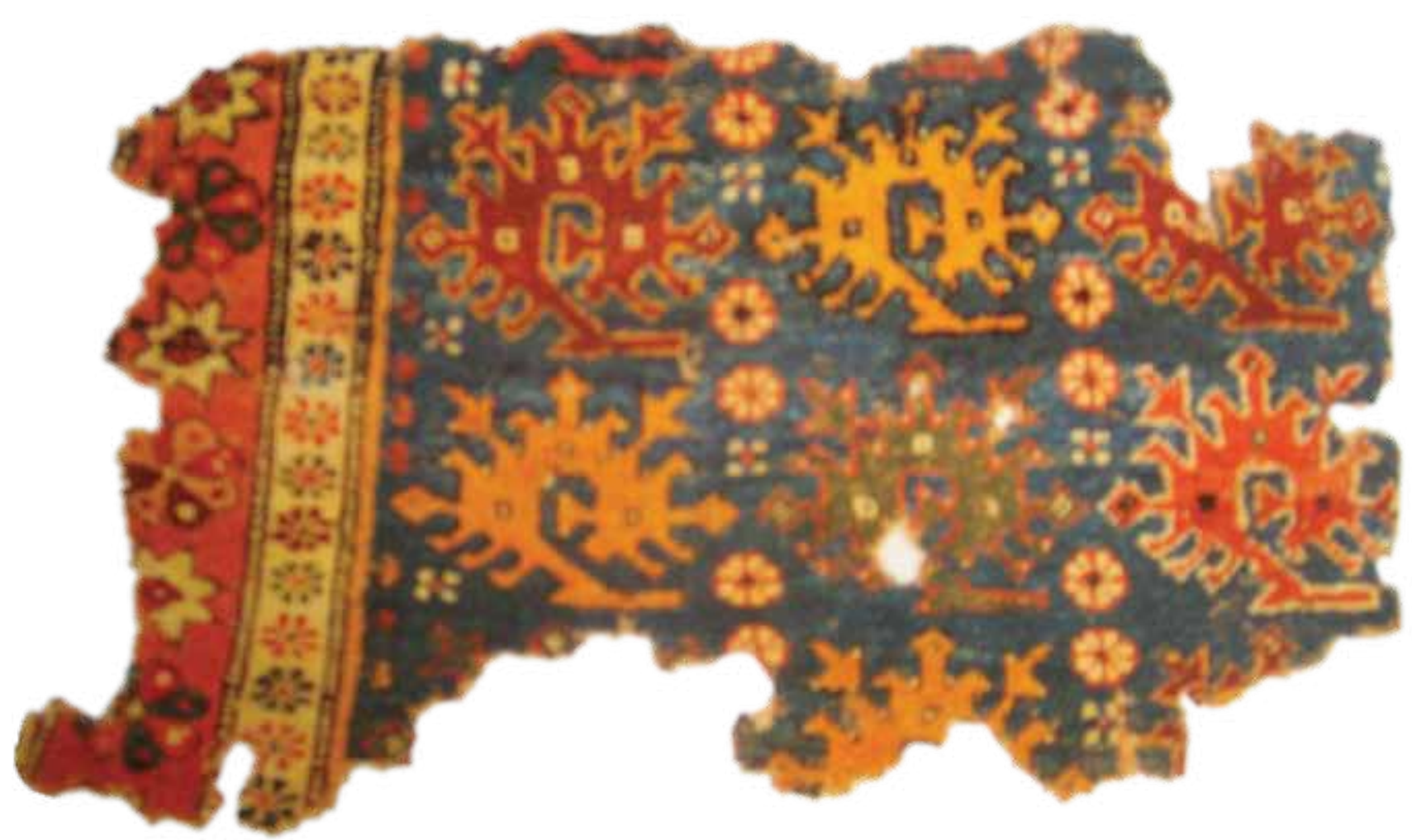

Foto 9. Ejder Motifli Halı Kültür Bakanlığı Katalog 1, Model Kodu:009

Ejder: Efsanevi bir hayvan olan ejder yer ve gök ejderi olarak iki cinse ayrılıyordu. Tasavvurlara göre ilkbahar geldiğinde yer ejderi yerin altından yukarı doğru çıkarak "kök-luu" denilen gök ejderinin özelliklerine sahip olur. Kanatları, boynuzları pulları ile değişimi tamamladıktan sonra bulutların arasında uçmaya başlar. Yağmurun yağmasına o sebep olur. (Çoruhlu 1993:243)

Hun Hükümdarları döneminde yüksek dağların zirvesindeki pınar veya göllerin sularında gök ejderlerinin belirdiğine dair bilgiler rivayet ediliyordu. Ejder, Çinlilerde ve İç Asya kavimlerinde gök tanrısı ve semavi inançlarla ilgili kullanılan sembollerden birisiydi. Ayrıca Hun hükümdarlarının gök ibadetine ejder ayini deniyordu. (Esin 1982:237)

Göktürk Kağanları da yılın en uzun günlerinde muhtemelen aynı yerde Temir ırmağının çıktığı yerde gök ayini icra ediyorlardı. Tengri Dağı Çince kaynaklarda kutsal olarak tanımlanmakta idi. Çin kaynaklarında yer alan bu törenlerle ilgili bilgilerde Göktürk Kağanın bir halı üzerinde havaya kaldırılıp, güneşi temsil eden ve göğü simgeleyen otağın çevresinde dokuz kere döndürüldüğü ifade edilmektedir (Esin 2006: 35)

Çift ejder eski Türklerde gök kubbenin sembolü idi. Çünkü tasavvurlara göre gök çarkını bir çift ejder çeviriyordu. (Çoruhlu 1993: 247) Eski Türkçe metinlerde büke, evren, luu, nek, kök-luu, obırga ,acırga, indel, endeks isimleriyle bilinir. (Deniz 1996:89) Çin ve Uygur kozmolojisinde doğunun, baharın, mavi ve yeşile denk gelen gök renginin ve ağacın simgesi idi. Türk Budist mabetlerinde gök gürültüsü ve yağmurun simgesi sayılıyordu.

Ejder figürü, Orta Asya'da dünyanın dönmesini sağlayan gece ve gündüzün oluşumunda, mevsimlerin değişiminde, kötülük, sağlık, kahramanlık sembolü olarak kullanılmıştır. Orta Asya ve Anadolu'da ejder çift veya çift başlı olarak resmedilmiştir. Mimari yapılarda mezar taşlarında şifahanelerde, kapı tokmaklarında küçük ev eşyalarında, halı ve kilimlerde en fazla kullanılan motiflerdendir.

Türk halı sanatında 15. yüzyıldan itibaren görülmeye başlayan ejder motifi, halıların bordürlerinde, mihraplarında, mihrap kemerlerinde, ayetliklerde, orta zeminde kullanılmıştır (Foto 10). Osmanlı dönemi XVII. yüzyıl Beyaz zeminli veya Post zeminli Uşak Halılarının bordürlerinde (Foto 11.) Çin bulutu şeklinde olup, motif orta yerinden dügüum yapmış şekilde işlenmiştir.Kömürcü Kula halılarında ise XVIII-XIX yüzyıl örneklerinde ejder motifi işlenmeye başlamıştır.Ayetliğin olmadığı halılarda çift başlı ve iki yöne doğru hareket eder şekilde ve başları lale şeklindedir. (Foto 12.) Günümüz Kula halılarında bordürlerinde ve halının orta zemininde eşkenar dörtgen şeklindeki göbeğin iki yanında yer alır. (Deniz 1998:104)

Kırşehir halılarında sandık diye tabir edilen dikdörtgen çerçeveler içinde yer alır.Buradaki ejder motifler "S" şeklinde olup enine yerleştirilmiştir. 


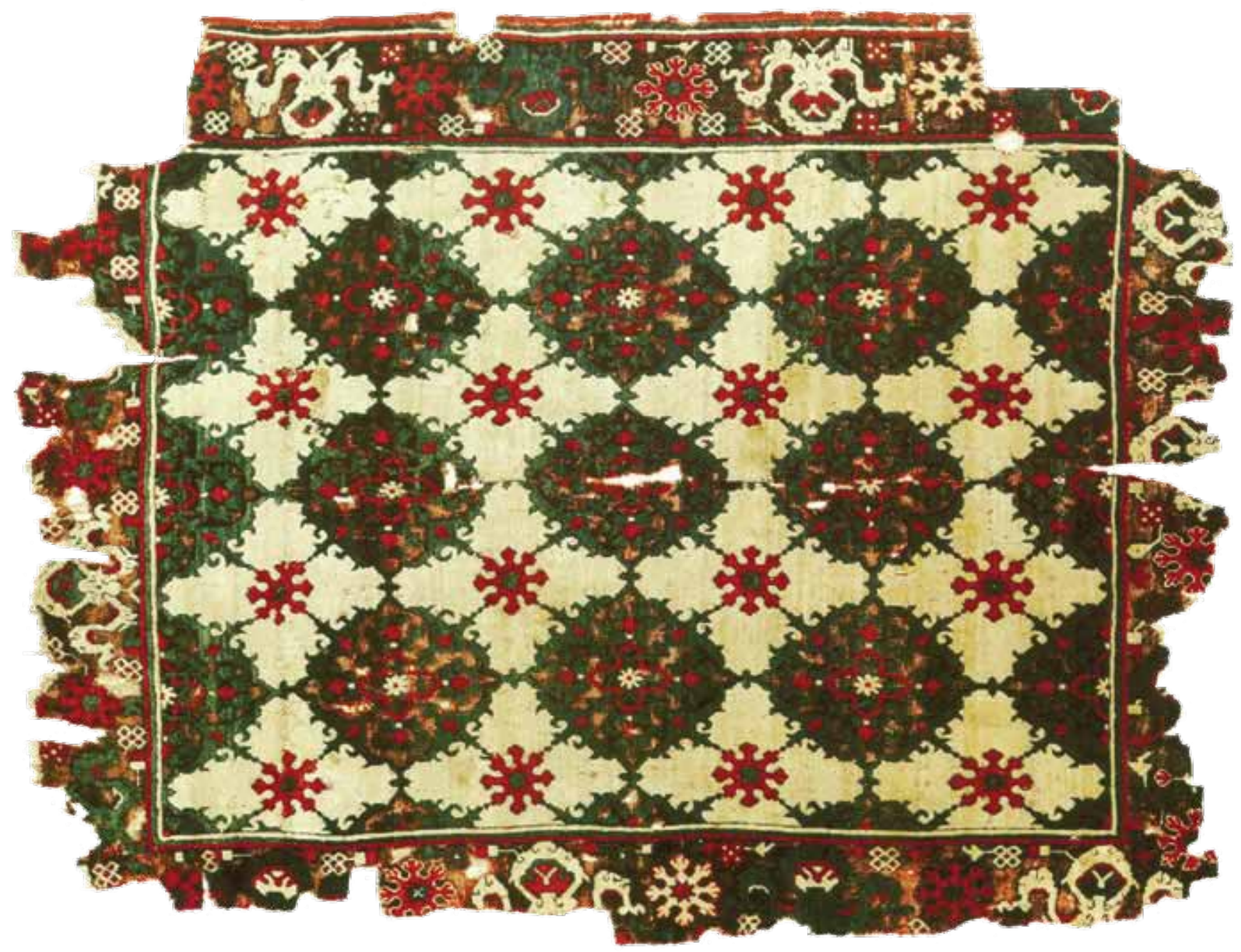

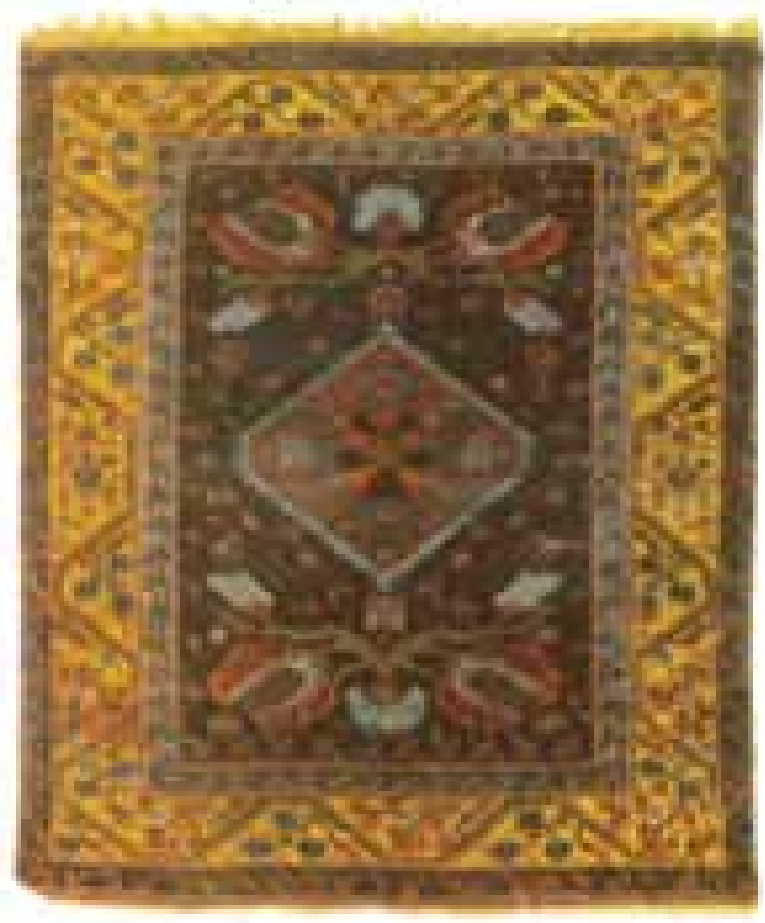

Foto 11. Kula Halısı (Ejderli), Model Kodu: 0126
Anadolu'da ejder motifinin farklı bir ifadesi ise yılan motifidir. Büyük yılana halk arasında evren de denir. Yılan, daha çok gerçek olarak tasavvur edildiğinden, insanların korktuğu hayvanlardan biridir. Insanlar korktukları ve kendilerine zarar veren bu hayvanı çeşitli şekillerde halı ve kilimlere ve pek çok kullanım eşyasına işlemişlerdir. Ayvacık yöresi halılarında ise XIX. yüzyıl örneklerinde halının kenar bordürlerinde görülür.

Milas Halılarında ise halının orta zemininde kıvrım şeklinde yer alır. Bu tür halılara yörede Yılanlı Milas denilmektedir. (Deniz 1998:104) .)Anlatılan bir hikâyede yöreye yerleşen bir beyin uzun zamandır hasretini çektiği bir erkek çocuğu dünyaya gelir. İki ağaç arasına asılan beşikte çocuk uyurken yılan sokar ve çocuk ölür. Çocuğu ölen anne, üzerinde yılan motifi bulunan bir halı dokur. Dokuduğu bu halıyı kapı önüne serer. Kapıdan her giriş çıkışında yılanın üstüne basarak yılandan çocuğunun intikamını alır (Foto 13). Milas geleneksel evlerinden olan ve 19. yüzyıla tarihlenen Hacı Kadı evinin tavan göbeğin- 


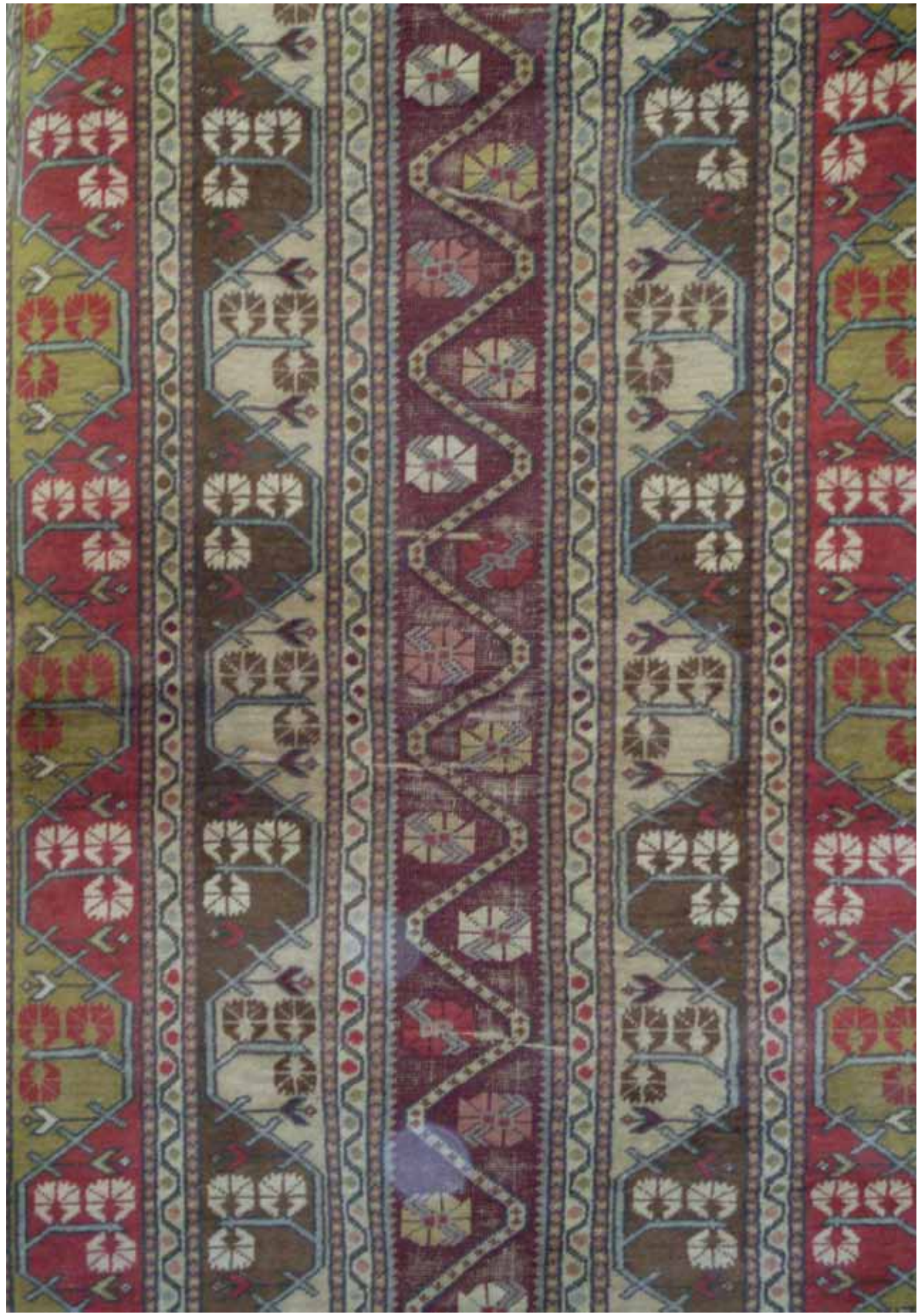

Foto 12. Yılanlı Milas halısı (Akgül Halı) 


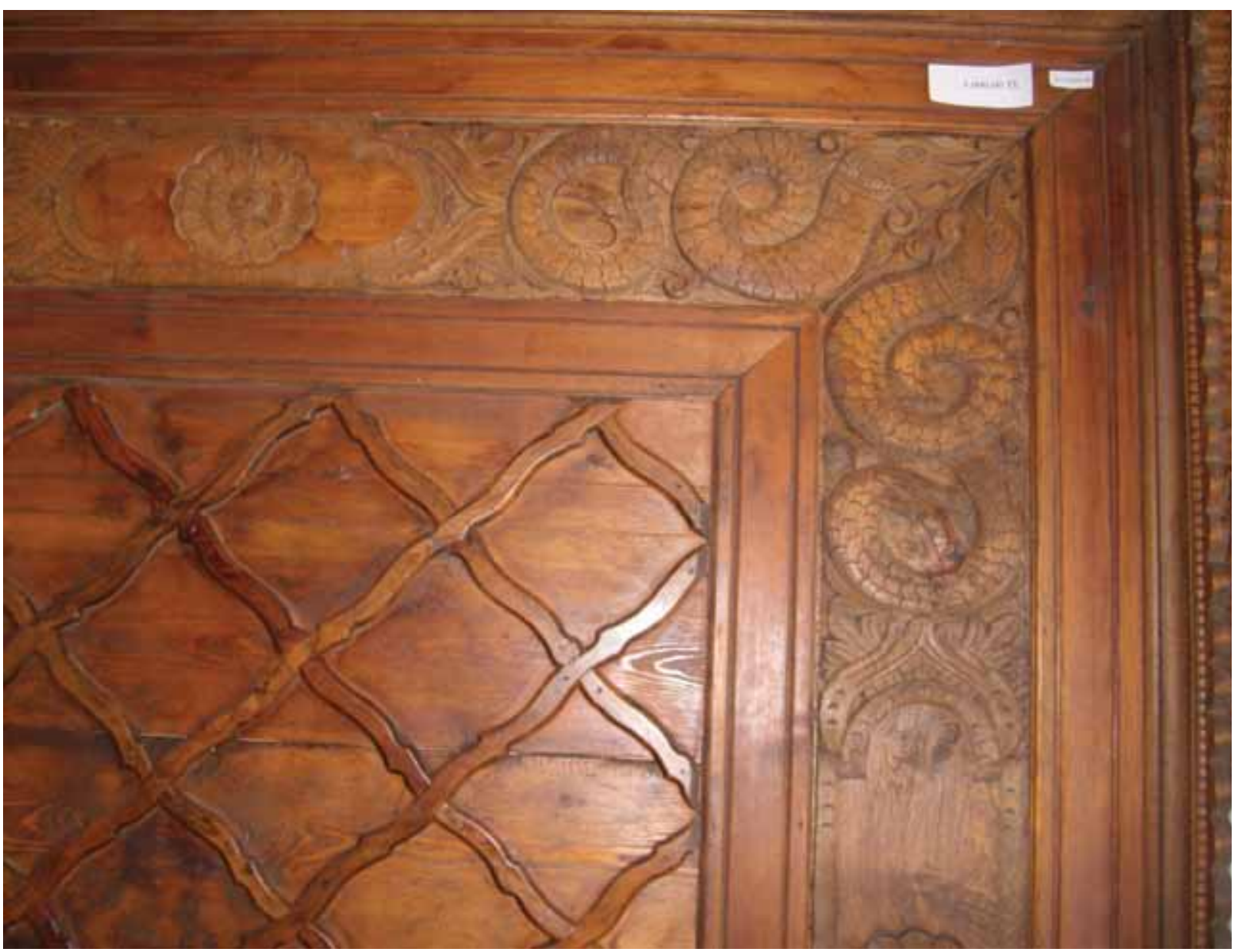

Foto 13. Milas Hacı Kadı Evi Tavan Göbeği Yılanlı Repredüksüyon Çalışması( Muğla Ünv. Milas Sıtkı Koçman M. Y.O. Restorasyon Programı)

de her köşede çifter yılan motifi yer alır. Yöresinde "Yılanın başı küçükken ezilir" atasözü kötülüklerden kurtulmayla ilgilidir.

Anadolu dışındaki Türk boylarına ait halılarda da ejder figürleri yer alır. Azerbaycan halılarında ejder figürü, 15. yüzyıldan itibaren görülmeye başlar ve iyi kuvvetleri temsil ettiğine inanılır. (Esedova 2008:517)

Muğla ili Ula ilçesi Sarayyanı Köyü'nde seyrek dokumalı cicimlerde kullanılan kıvrımlı yanışa yörede dolaşa denmektedir. Dolaşa ismi yörede "yılan" anlamında kullanılmaktadır. Yine bu köye yakın olan Örnek köyün eski ismi Dolaşa'dır. İnsanlar kendilerine zarar vereceğine inandığı varlıkların ismini olarak kullanmak istemezler.Yılana tehlikesinden uzak olmak için "dolaşa", cini "üç harfli" olarak ifade ederler.

\section{Değerlendirme ve Sonuç:}

Halı ve kilimlerimizin yüzeylerini süsleyen motifler, sadece bir şekilden ibaret olmayıp, kültürümüzün en eski çağlardan başlayarak günümüze kadar yaşatılmış mana yüklü sembolleridir. Halı ve kilimlerimizde yer alan motiflerin Mimari eserlerimizde kabartma şeklinde, çini levhalarda, ahşap süslemelerinde hat sanatında, halk işlemelerinde minyatürlerde, Türk destanlarında, efsanelerinde, masallarında, yazılı edebiyat eserlerinde ve süsleme sanatlarında kullanılmış olması kültür bütünlüğümüzün İfadesidir. Araştırılan dört motif bu görüşü doğrulamakta.Halı yüzeyinde yer alan her motif bir veya birden çok anlam içermekte.Sanki geçmişten günümüze yazılmış sır dolu bir sözleşme gibidir. Motifler incelendiğinde zamanla bazı değişmelere uğradığı gözlenebilmektedir. Örneğin İslamiyet öncesi döneme ait olan Pazrık Halısında hayvan motifleri realist olarak işlenirken İslami dönemde motiflerin stilize edilerek kullanıldığını görüyoruz. İslam inancında özellikle ibadet amaçlı yapılan camilerin içini tefriş etmede kullanılan halılarda motifler soyut veya bitkisel karakterlidir.Her iki dönemde mitoljik kaynaklı motifleri kullanılması düşünce dünyasını aynı olduğunu, manaların döneme göre mâna kazandığını görüyoruz. Örneğin Geyik kutsal bir av hayvanı ve ongun iken İslami dönemde yol göstericidir Kartal güç kuvvet ve bağımsızlık simgesi olmasının yanı sıra göklerin ve yerin hakimi, adaletin temsilcisidir. Ejder yer altı dünyasının hâkimi, kötülüklerin engelleyicisi, ma- 
betlerin koruyucusudur.Hayat ağacı hem İslamiyet öncesinde hem de İslami dönemde üç alemin birbirine bağlantısını ifade etmektedir.Halılarımızdaki bu motiflerbazı değişiklikler geçirmiş olsa da günümüze kadar yaşatılması geçmişle olan bağın kuvvetliliğini ifade etmesi açısından önemlidir.Türk Dünyasının halı ve kilimlerini incelediğimizde bu motiflerin, ortak motif olduğunu görüyoruz. Günümüz halılarında var olan bu motifler, çok çeşitli coğrafyalarda yaşayan Türk milletin kültür bütünlüğü açısından da önemlidir.. motiflerin halı ve kilimlerimizde yer alması halı ve kilimlerimizin anlatım dilinin zenginliğini ifade eder.Halıların yüzeyinde yer alan her motifin anlamı çıkartılarak o halının anlatım dili ortaya konabilir.Bu yöntemle her halının ayrı bir öyküsü ortaya çıkarılabilir.Bu yöntemle halılarımızın daha iyi tanıtılması sağlanabilir.

Türk sanatının en eski çağlarından bu güne kadar meydana getirilmiş tüm sanat eserleri incelenerek benzerlikler ve farklılıklar ortaya konmalıdır.

\section{Kaynaklar}

Arık, Rüçhan (1987), Selçuklu Saray ve Çinileri, Türkiye İş Bankası Kültür Yayınları Genel Yayın No.514 İstanbul, 2000.

Aslanapa, Oktay (1984), Türk Halı Sanatının Bin Yll, Eren Yayıncılık ve Kitapçılık, İstanbul.

Aslanapa, Oktay, Türk Sanatt, İstanbul.

Atiş Özhekim, Didem (01-02 Kasım 2007), "Hayvan figürlü Tekstillerde Kartal Sembolü" I. Uluslararası Türk El Dokumaları Kongresi, Konya.

Atnur, Gölhan (2003),“Kozı Körpeş ile Bayan Sulu Destanında Geyik Motifi", Atatürk Üniversitesi Türkiyat Araştırmaları Enstitüsü Yay. S.28, Erzurum, M. Fahreddin Kırzıoğlu Özel Sayısı, s. 213-222.

Aytaş, Gıyaseddin, “Türk Kültür ve Edebiyatında Geyik Motifi, ve "Haza Destan-1 Geyik", http/www.hbektaşiveli. gazi.edu.tr/dergi dosy/12-161-170.

Aytaç, Gülsüm, "Türk Kültüründe Keseler" Sanat ve Insan Dergisi, E-dergi

Banarlı, Nihat Sami (1971), Resimli Türk Edebiyatı Tarihi, 1.Fasikül, İstanbul

Barışta, Örcün (2001), Cumhuriyet Dönemi Türk Halk İ̧lemeciliği Desen Terminolojisinden Örnekler, Kültür Bakanlığı Yayınları Yayın No: 2566, Halk Kültürünü Araştırma ve Geliştirme Genel Müdürlüğü. Yay. 311 Maddi Kültür Dizisi:29, Ankara.

Beksaç, Engin (1988), "Atlı Ağaç ve Kadın" Orta Asya'dan Anadolu'ya Türk Sanatı ve Kültürü, Prof. Dr. Nejat Diyarbekirli'ye Armağan, Ankara, s. 63-98.

Cıblak, Nilgün, "Tarsus Kültürünü Tanıtımında Şahmeran Efsanelerinin Önemi", Çukurova Üniversitesi Sosyal Bilimler Enstitüsü Dergisi, C. 16, S. 1, s.185-196.

Çelik, Adem (2002), "Niğde Sungur Bey Camiinde Bulunmuş Olan Çift başlı Kartal Figürlü Halı Üzerine Düşünceler" Atatürk Üniversitesi Güzel Sanatlar Fakültesi Dergisi, S.9. s. 45-59.

Çoruhlu, Yaşar, "Türk Sanatında Görülen Hayvan Figürleri” III. Türk Kültürü Kongresi, C. 1, s. 243-257.

Deniz, Bekir, "Le Motifs du dragons dans lestissags d'AnatieTurc (Anadolu Türk Dokumalarında Ejder Motifi"
Türk Soylu Halkların Hall, Kilim Cicim Sanatı Uluslararası Bilgi Şöleni Bildirileri, 27-3 Mayıs 1996. Basım Yılı 1998, s.87-108

Deniz, Bekir (2006),"Kazak Halı ve Düz Dokuma Yaygılarında Motif Özellikleri" Uluslararası Geleneksel Sanatlar Sempozyumu Bildirileri, Dokuz Eylül Üniversitesi, İzmir.

Deniz, Bekir (2000), Türk Dünyasında Halı ve Düz Dokuma Yaygllar, Atatürk Kültür Merkezi Yayınları, Ankara.

Ergin, Muharrem (2007), Dede Korkut Kitabı, Boğaziçi Yayınlar1 37.bask1, İstanbul.

Ergun, Pervin (2008), Türklerde Ağaç Kültü, Atatürk Kültür Merkezi Başkanlığı Yay., Ankara.

Esedova Velikızı, Hatice (2008), "Halılarda Mitoloji" 1015.09.2007 Ankara 38. ICANAS, C.2, Atatürk Kültür Merkezi Başkanlığı Yay., Ankara, s. 517-544.

Duymaz, Ali (2008), "Türk Folklorunda Dış Ruh Tasarımı" Bilig Dergisi, bahar, S. 45 s.1-22.

Esin, Emel (2006), Türklerde Maddi Kültürün Oluşumu, Kabalcı Yayınevi, İstanbul.

Esin, Emel (1982), Türklerde "Tengrilik" (Türklük ve Gök Tapınağına Dair') Sanat Tarihi Yillı̆̆ı, XII, Sanat Tarihi Araştırmaları Merkezi, İstanbul, s. 35-51.

Gönül, Macide (1965), “Türk Halı Ve Kilimlerinde Sembolik Kuş Şekilleri" Antropoloji, 3, Ankara, s. 199-27.

Görgünay Kırzıoğlu (2001), Altaylardan Anadolu'ya Türk Dünyasında Ortak Yanışlar, Kültür Bakanlığı Yayınları:2753 Sanat Eserleri Dizisi:366, Ankara.

Gülensoy, Tuncer (1989), Orhun'dan Anadolu'ya Türk Damgaları TDAV Yay. İstanbul.

İnal, Güner (1995), Türk Minyatür Sanatı Ankara.

Kafesoğlu, İbrahim (1984), Türk Milli Kültürü, Boğaziçi Yayınları, İstanbul.

Karamağaralı, Beyhan (1970), "Sivas ve Tokattaki Figürlü Mezar Taşları Hakkında" Selçuklu Araştırmaları Dergisi, II, s. 75-103.

Karamağaralı, Beyhan (1976), "Anadolu'da XII.-XVI. Asırlardaki Tarikat ve Tekke Sanatı Hakkında" Ankara İlahiyat Fak. Dergisi, Ankara, s. 247-267.

Mülayim, Selçuk (1999), Değişimin Tanikları Ortaçağ Türk Sanatında Süsleme ve İkonografi, Kaknüs Yay. İstanbul.

Ögel, Bahaddin (1998), Türk Mitolojisi, C. 1., Türk Tarih Kurumu Basımevi, Ankara.

Ögel, Bahaeddin (1984), İlamiyetten Önce Türk Kültür Tarihi, Türk Tarih Kurumu Basımevi, Ankara.

Önder, Mehmet, "Selçuklu Kubad-abad Sarayı Çinileri”, Kaynaklar Dergisi, Ankara, sayı 4, s.17-21.

Öner, Esra (2008), "Gevheri Divanında Kuşlar", Uluslararası Sosyal Araştırmalar Dergisi, The Journal of İnternational Socials Research Volum, 1/5 Fool.

Parlar, Gündegül (2000), Anadolu Selçuklu Sikkelerinde Yazı Dışı Figüratif Öğeler, Kültür Bakanlığı Yay., 2597, Sanat Eserleri Dizisi:321, Ankara.

Salman, Özlem (1998), "Türk Sanatında Gerçek Dışı Varlık Motifleri", İlgi Dergisi, S. 92, s. 8-12.

Tekçe, Fuat (1993), Altaylardan Bir Halının Öyküsü Pazırık, Kültür Bakanlığı Yayınları, Yayın No: 1542, Ankara.

Uzun, Tolga (1996), “Türk Sanatındaki Kartalların İkonografisi ve Devamlılığı" PAÜ Eğitim Fak. Dergisi, S:1, s. 82-89, Denizli.

Yetkin, Şerare (1974), Türk Halı Sanatı, Ankara 